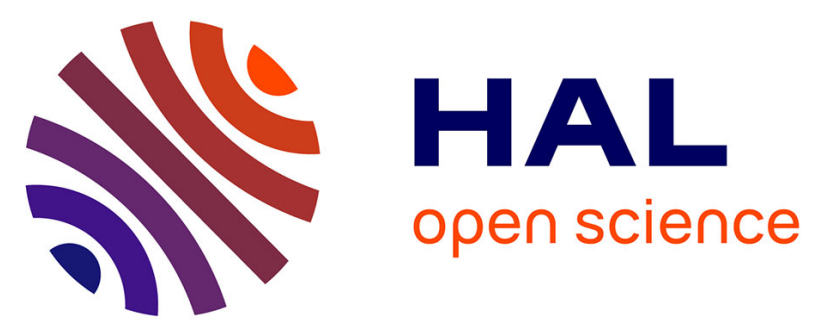

\title{
India-Asia collision paleogeography constrained by Burma Terrane (Myanmar) Late Cretaceous to Miocene paleomagnetic data
}

Jan Westerweel, Pierrick Roperch, Alexis Licht, Guillaume Dupont-Nivet, Zaw Win, Fernando Poblete, Nathan Cogné, Gilles Ruffet, Et Al.

\section{To cite this version:}

Jan Westerweel, Pierrick Roperch, Alexis Licht, Guillaume Dupont-Nivet, Zaw Win, et al.. IndiaAsia collision paleogeography constrained by Burma Terrane (Myanmar) Late Cretaceous to Miocene paleomagnetic data. European Geosciences Union General Assembly, Apr 2020, online, Austria. pp.EGU2020-1523. insu-02539606

\section{HAL Id: insu-02539606 \\ https://hal-insu.archives-ouvertes.fr/insu-02539606}

Submitted on 16 Nov 2020

HAL is a multi-disciplinary open access archive for the deposit and dissemination of scientific research documents, whether they are published or not. The documents may come from teaching and research institutions in France or abroad, or from public or private research centers.
L'archive ouverte pluridisciplinaire HAL, est destinée au dépôt et à la diffusion de documents scientifiques de niveau recherche, publiés ou non, émanant des établissements d'enseignement et de recherche français ou étrangers, des laboratoires publics ou privés. 


\section{India-Asia collision paleogeography constrained by Burma Terrane (Myanmar) Late Cretaceous to Miocene paleomagnetic data}

Jan Westerweel ${ }^{1}$, Pierrick Roperch ${ }^{1}$, Alexis Licht ${ }^{2}$, Guillaume Dupont-Nivet ${ }^{1,3}$, Zaw Win ${ }^{4}$, Fernando Poblete ${ }^{1,5}$, Nathan Cogné ${ }^{1}$, Gilles Ruffet ${ }^{1}$, Huasheng Huang ${ }^{6}$, Hnin Hnin Swe ${ }^{7}$, Myat Kai Thi ${ }^{7}$, Carina Hoorn ${ }^{6}$, Day Wa Aung ${ }^{7}$ 


\section{Paleomagnetism Burma Terrane (BT), Myanmar}

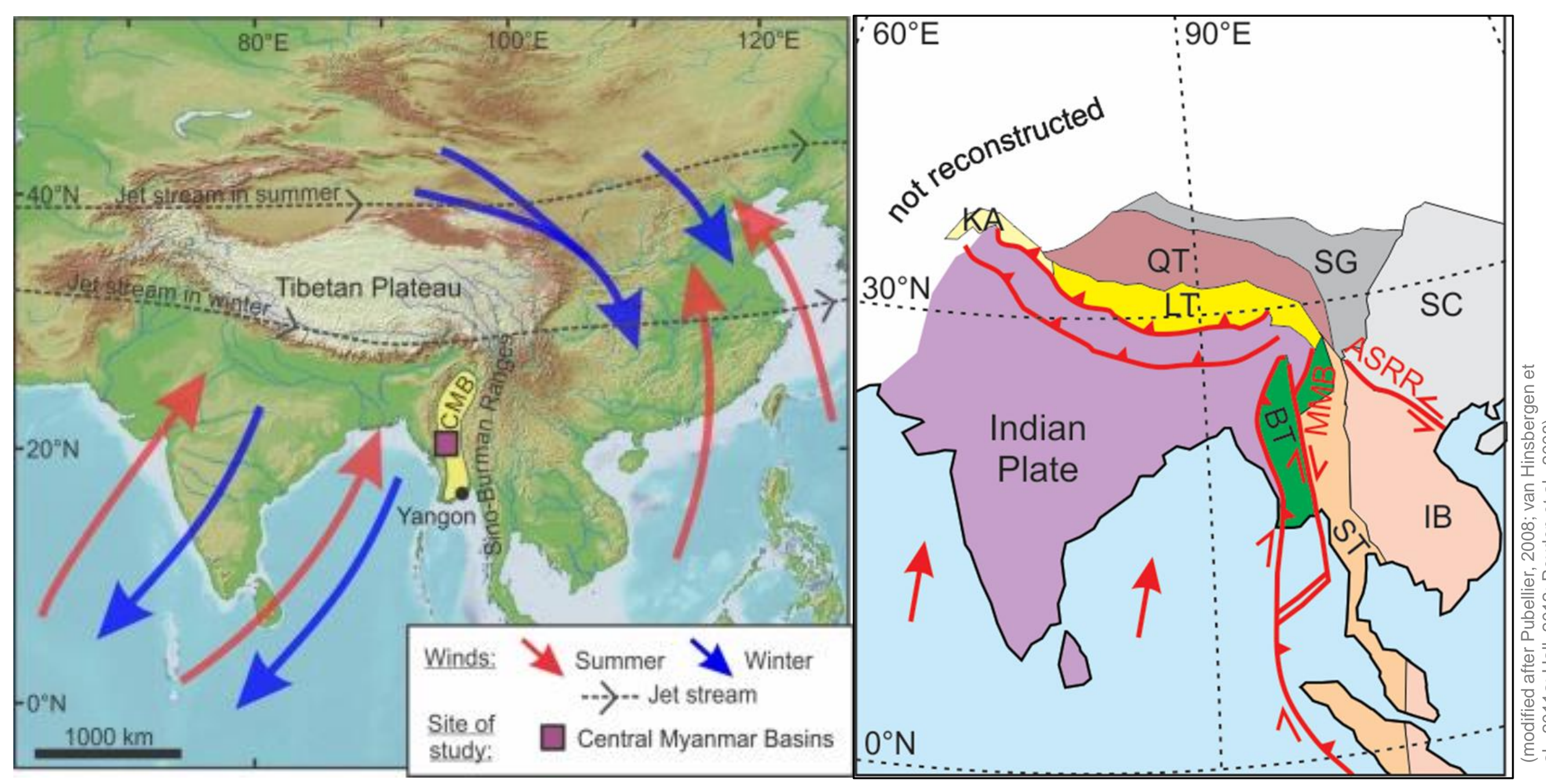

Paleolatitude Burmese monsoonal proxies

Asian tectonics

\section{Paleogeography Asia}




\section{Position Burma Terrane different for 3 scenarios India-Asia collision} (60 Ma)

a)

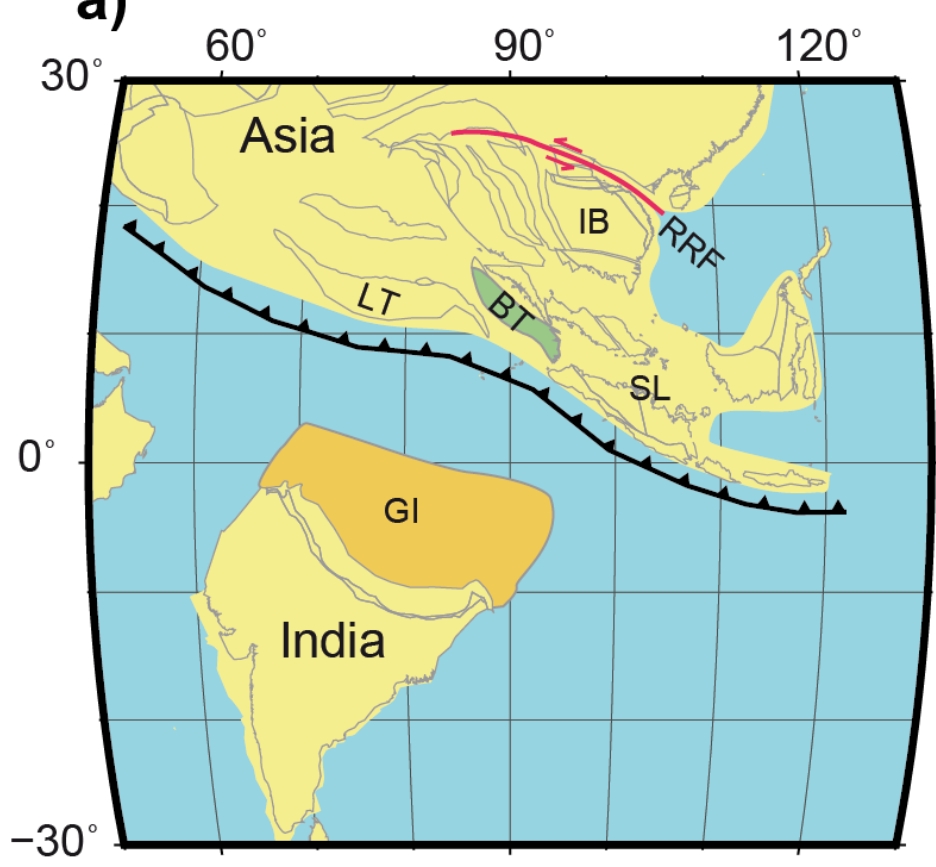

E-W subduction zone /

Significant extrusion Indochina

- Relatively high latitude

- Large clockwise rotation BT

(Cogne et al., 2013; Replumaz et al., 2010, 2013; Royden et al., 2008)

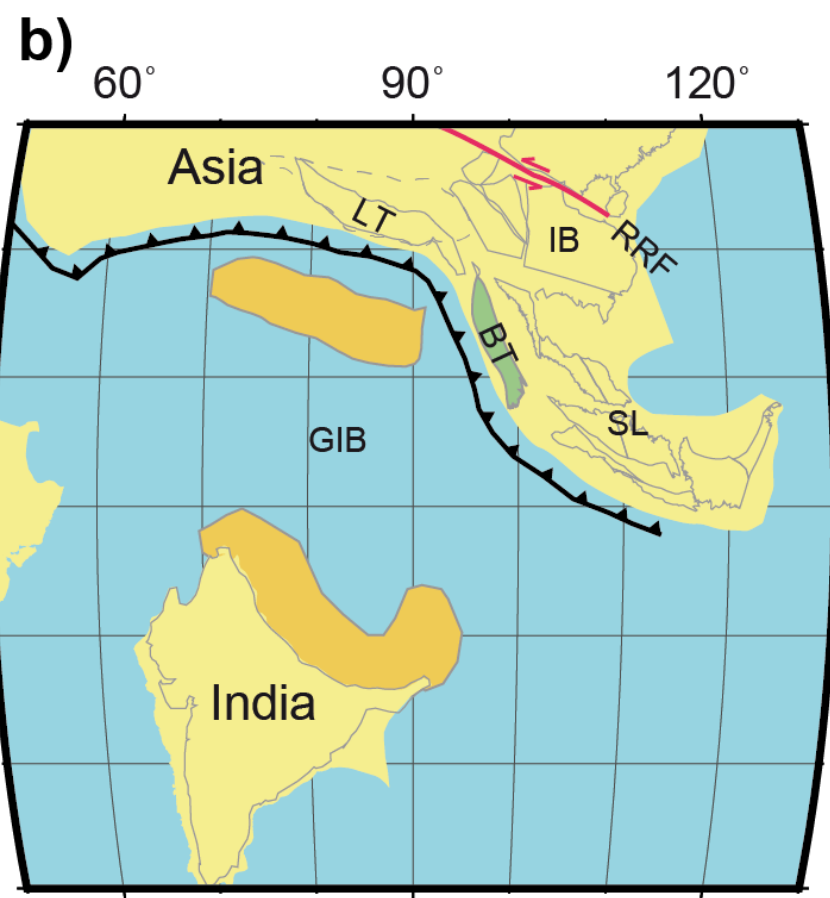

Greater India Basin (GIB)

- Relatively high latitude

- Little rotation BT

(Van Hinsbergen et al., 2012, 2018)

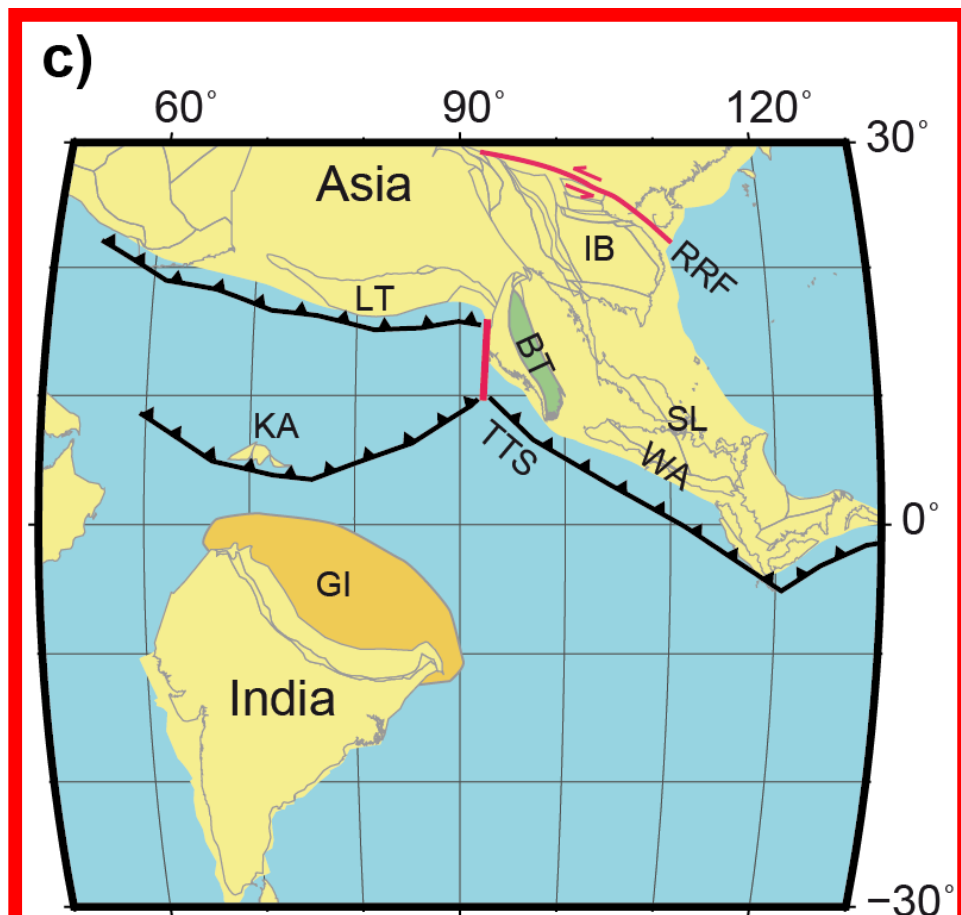

Trans-Tethyan Arc

- BT as part of Trans-Tethyan / Incertus Arc

- Paleolatitude less constrained, arc was potentially farther south

(Hall, 2012; Jagoutz et al., 2015, Zahirovic et al., 2016) 
Westerweel et al. (2019) - Paleomagnetic results 95 and 40 Ma: Near-equatorial latitudes for Burma Terrane

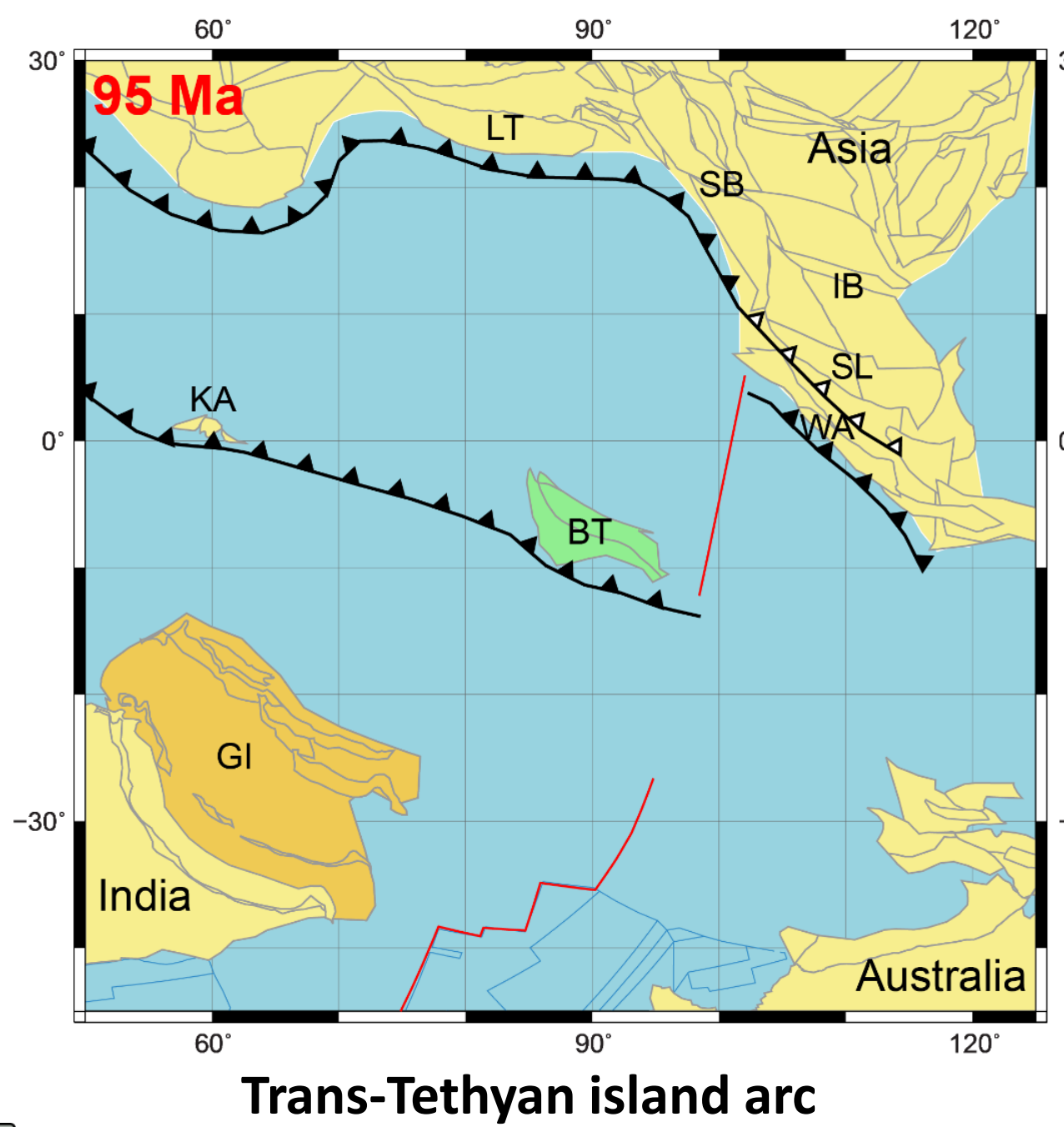

Andean-type volcanism

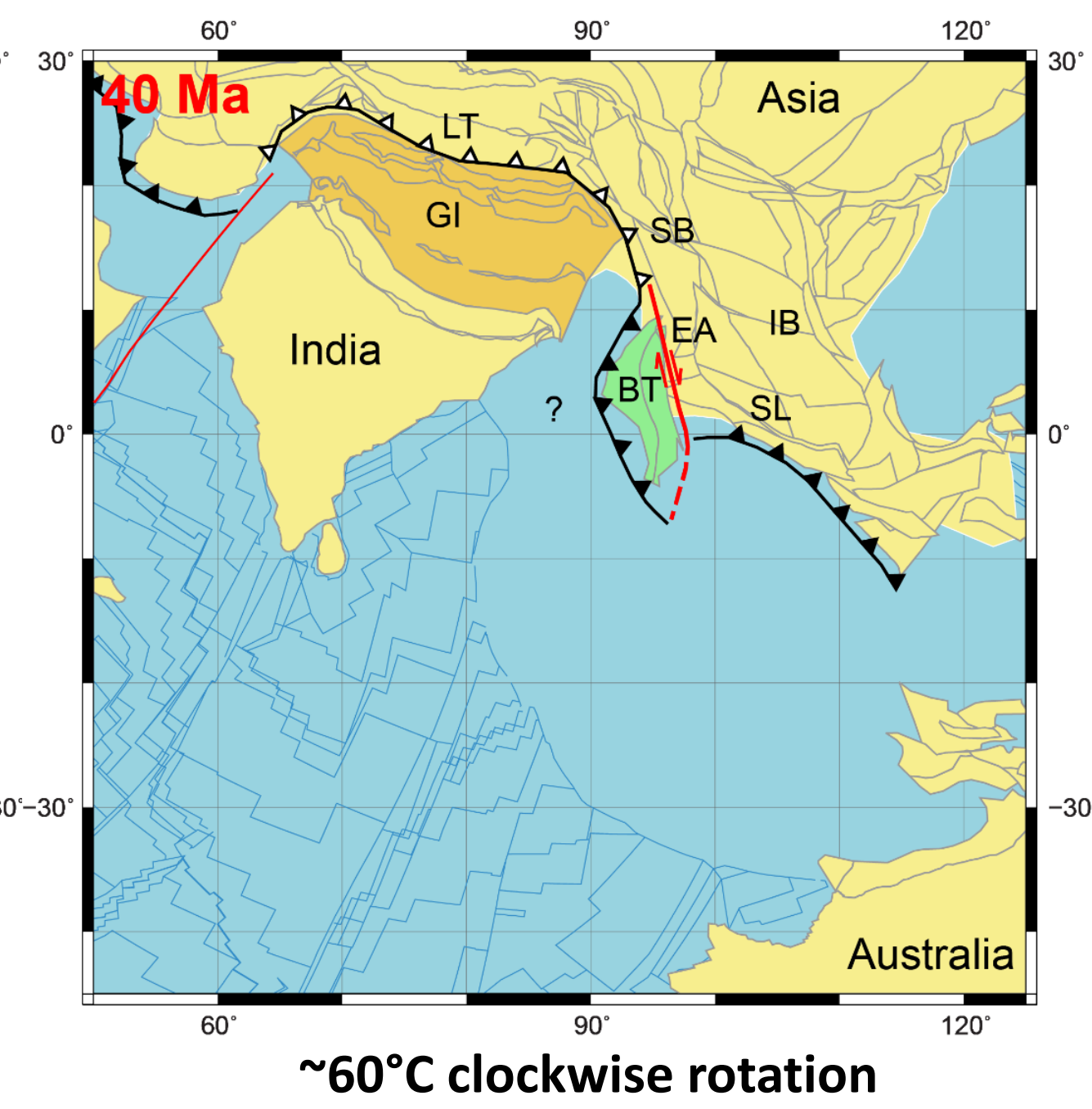

2000 km northward strike-slip motion 


\section{Questions}

- Pre-Cretaceous origin of the Burma Terrane

- When was the Burma Terrane incorporated onto the Indian Plate?

- What was the mechanism of clockwise rotation?

- When and where did Burma / eastern India collide with Sibumasu?

$\rightarrow$ Paleomagnetic sampling late Paleocene - middle Eocene, late Eocene, middle Oligocene, middle Miocene sediments in Myanmar (Burmese forearc basins)

$\rightarrow$ GPlates model of the India-Asia collision including deforming plates

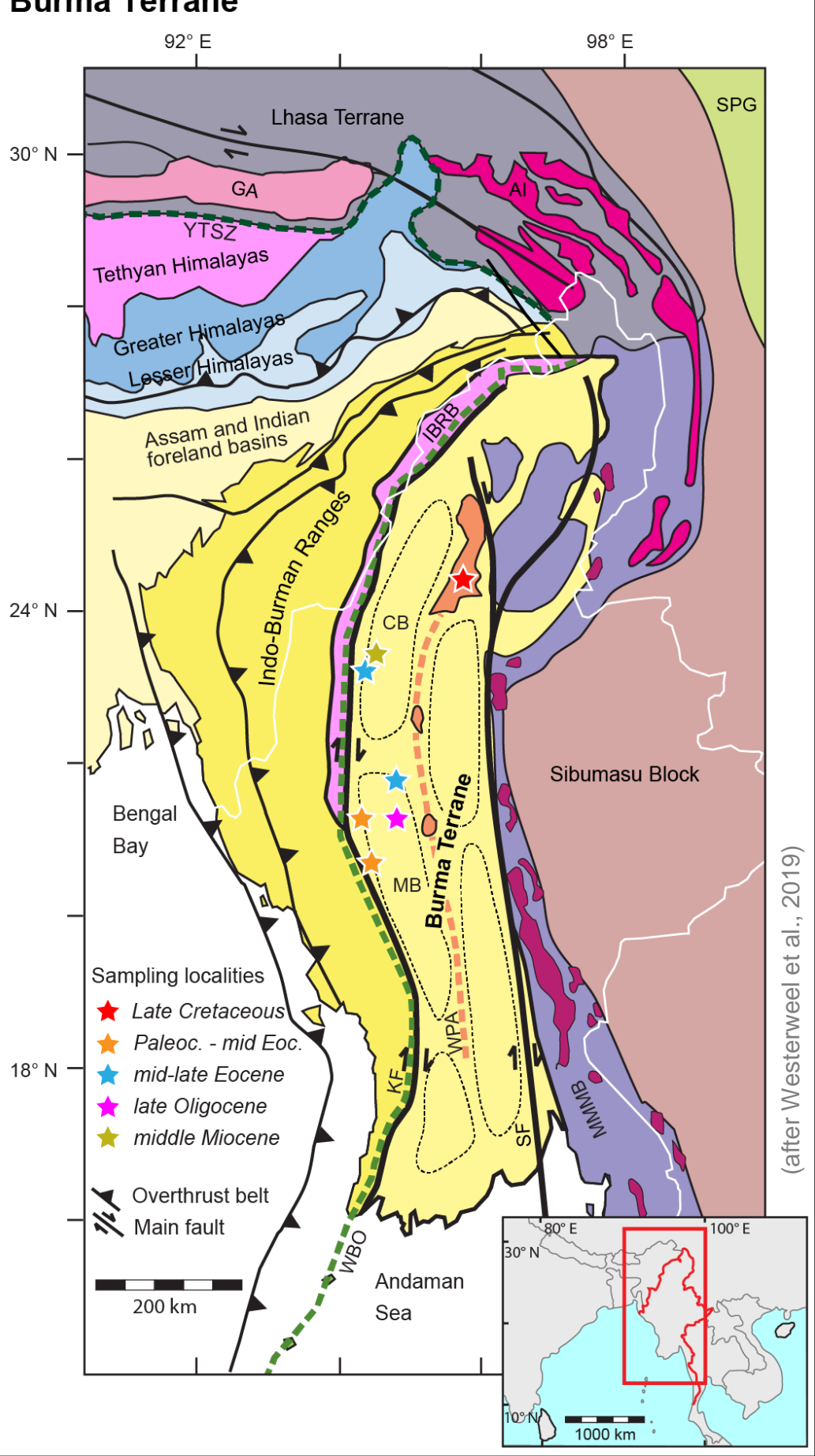




\section{Sampling Burmese forearc basins}

\section{Late Paleocene - middle Eocene (Minbu Basin)}

- Sidoktaya: 1 site in fresh grey mudstones, 2 sites in tuffs (71 samples)

- Saw: 7 sites in fresh grey mudstones and siltstones (63 samples)

- Ngape \& Datkon: 7 sites in tuffs and volcaniclastic sandstones (75 samples)

$\rightarrow$ Only fresh mudstones provided reliable stable magnetizations, tuffs Ngape \& Datkon highly scattered

\section{Late Eocene (Minbu Basin)}

- Pondaung Ranges: 9 sites, 89 samples in paleosols

\section{Middle Oligocene (Minbu Basin)}

- Tantkyitaung Pagoda (Bagan): 3 sites, 31 samples in fresh siltstones

\section{Middle Miocene (Chindwin Basin)}

- Kalewa: 27 sites, 219 samples in paleosols

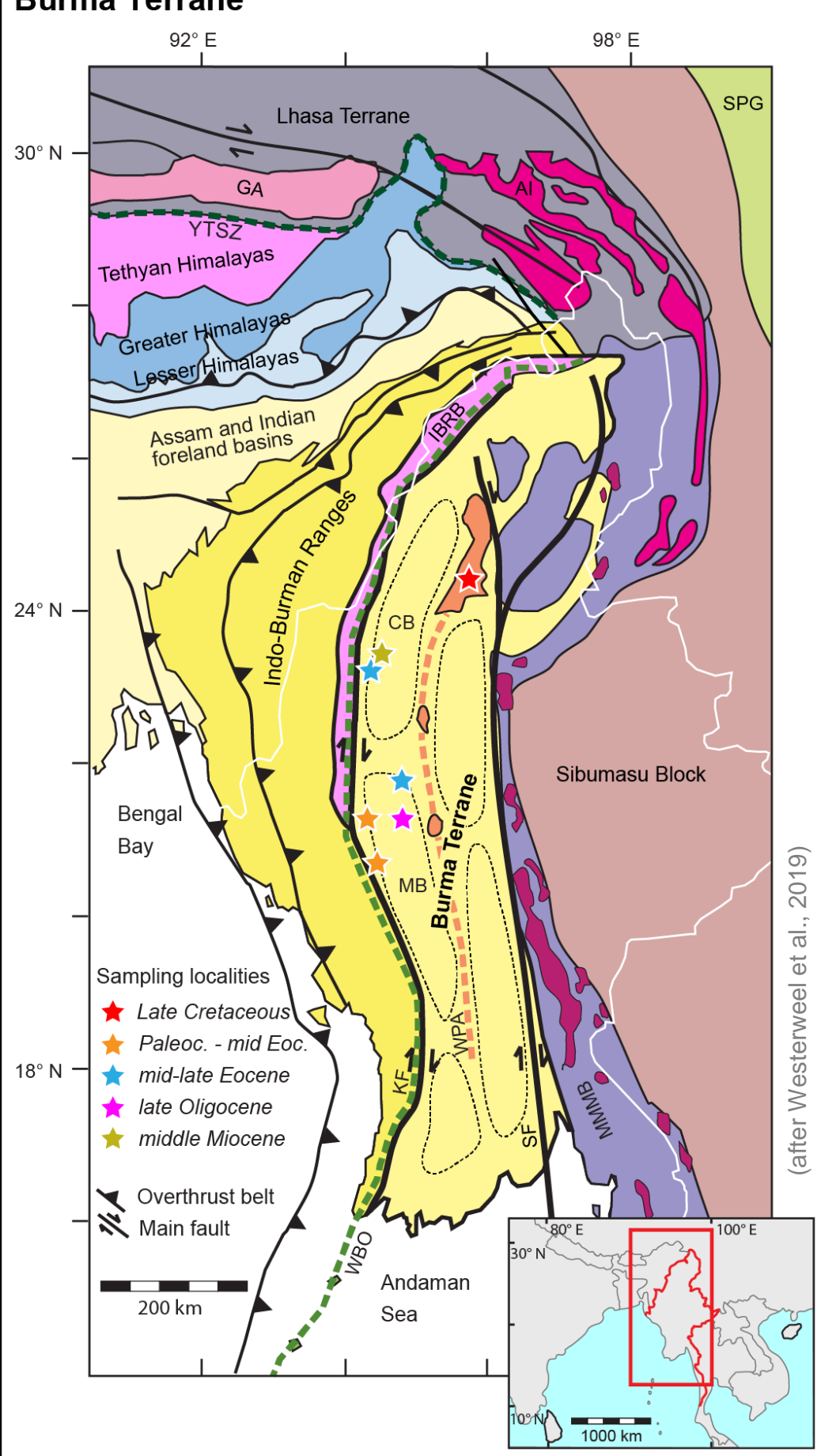




\section{Results: late Paleocene - middle Eocene}

\section{Sidoktaya}

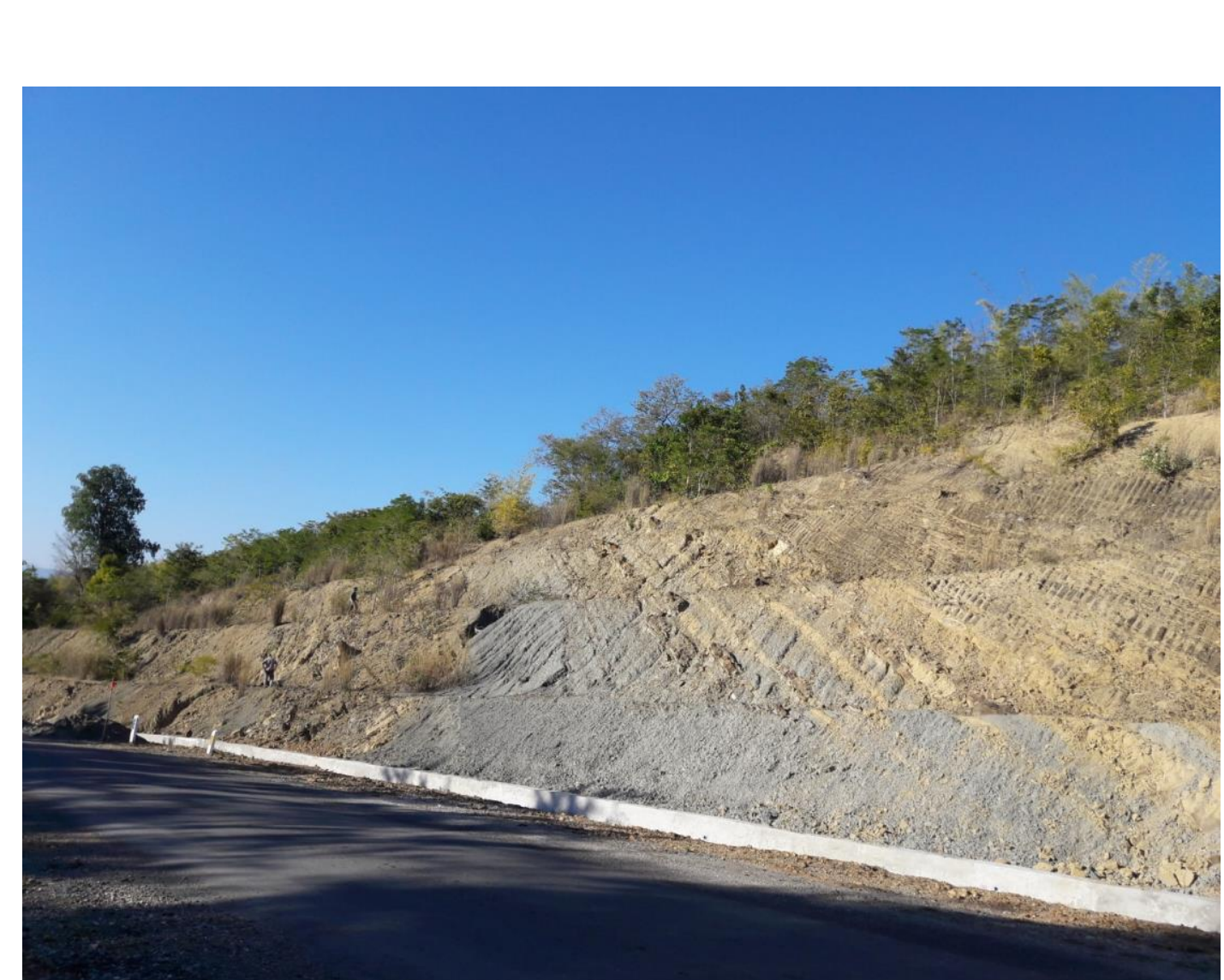

- Paunggyi and Laungshe Fms.

- Minbu Basin

- 37 samples in fresh blue-grey mudstones \& tuffs

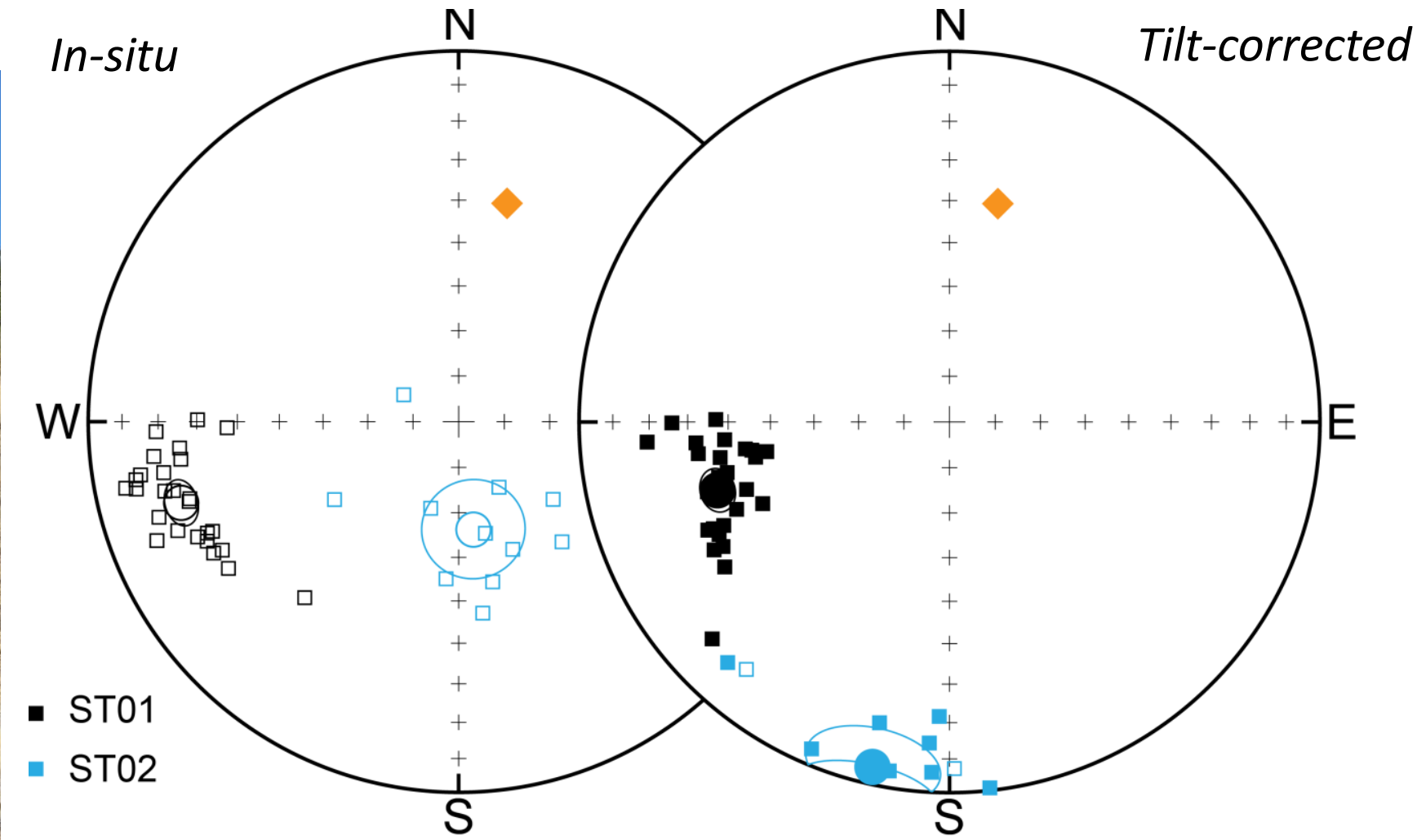

- ChRM different from present-day field and with reverse polarity (Magnetic field mostly reversed at this time)

- Site ST01: Very stable ChRM. Positive inclination/reverse polarity after tilt correction implies a southern hemisphere paleolatitude

- Site ST02 less good, more scatter $\rightarrow$ local deformation 


\section{Results: late Paleocene - middle Eocene}

\section{Saw}

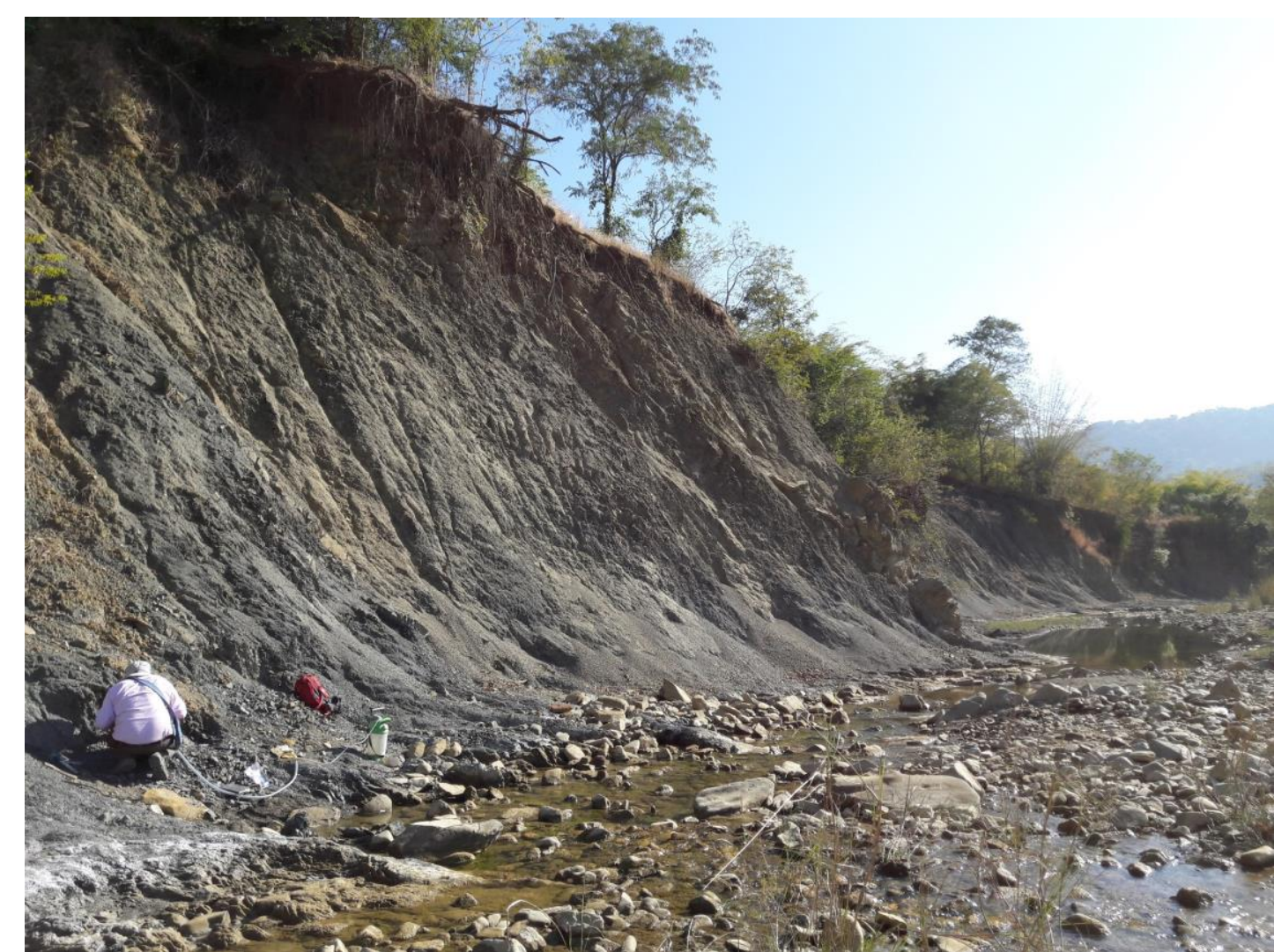

- Laungshe and Tilin Fms.

- Minbu Basin

- 34 samples from fresh blue-grey mudstones

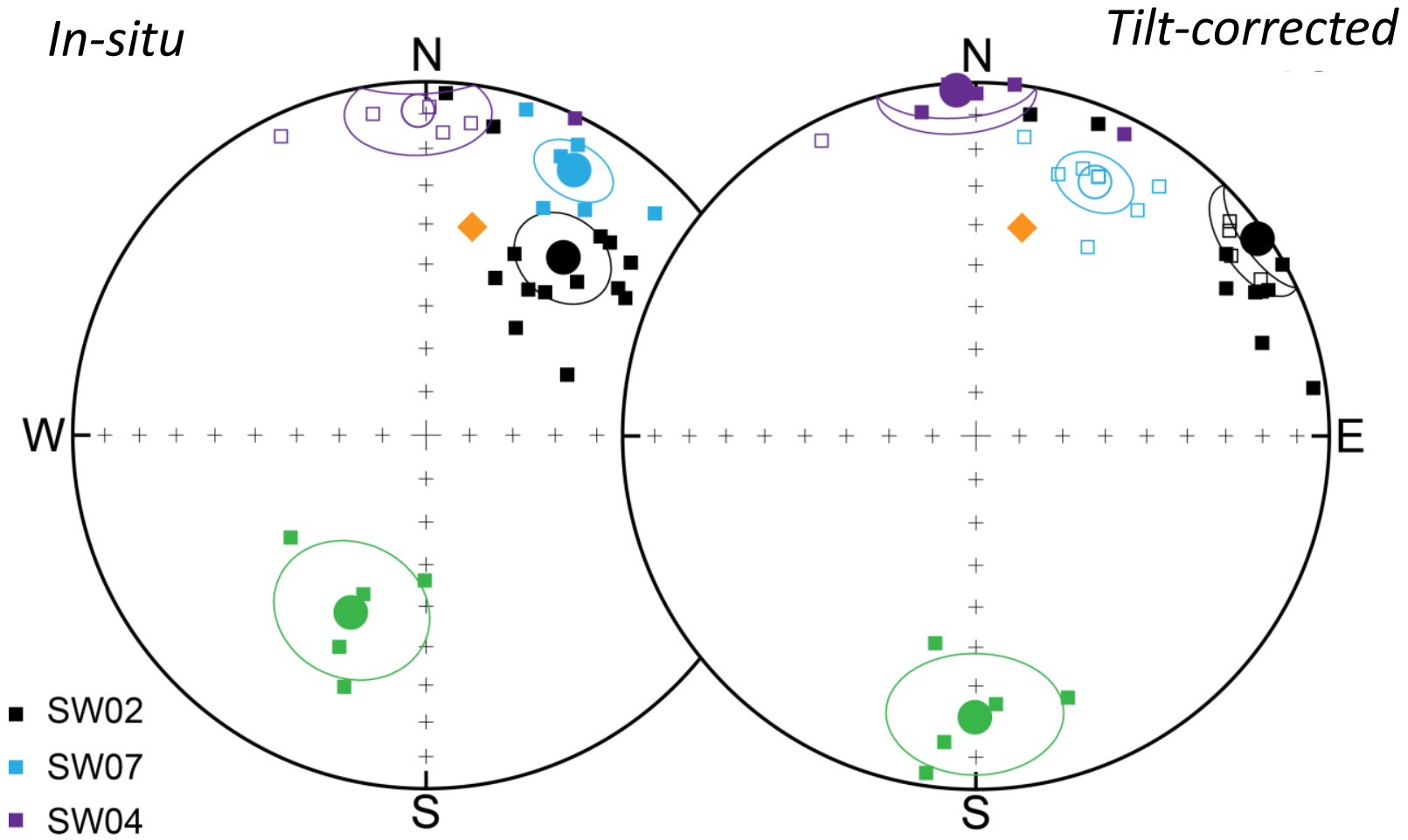

- SW03

- Declinations sites SW02 and SW07 same eastward trend as Sidoktaya (see previous slide)

- Declinations sites SW03 and SW04 affected by local faulting

- Inclinations in all sites give southern to near-zero latitudes 


\section{Results: late Paleocene - middle Eocene} Saw

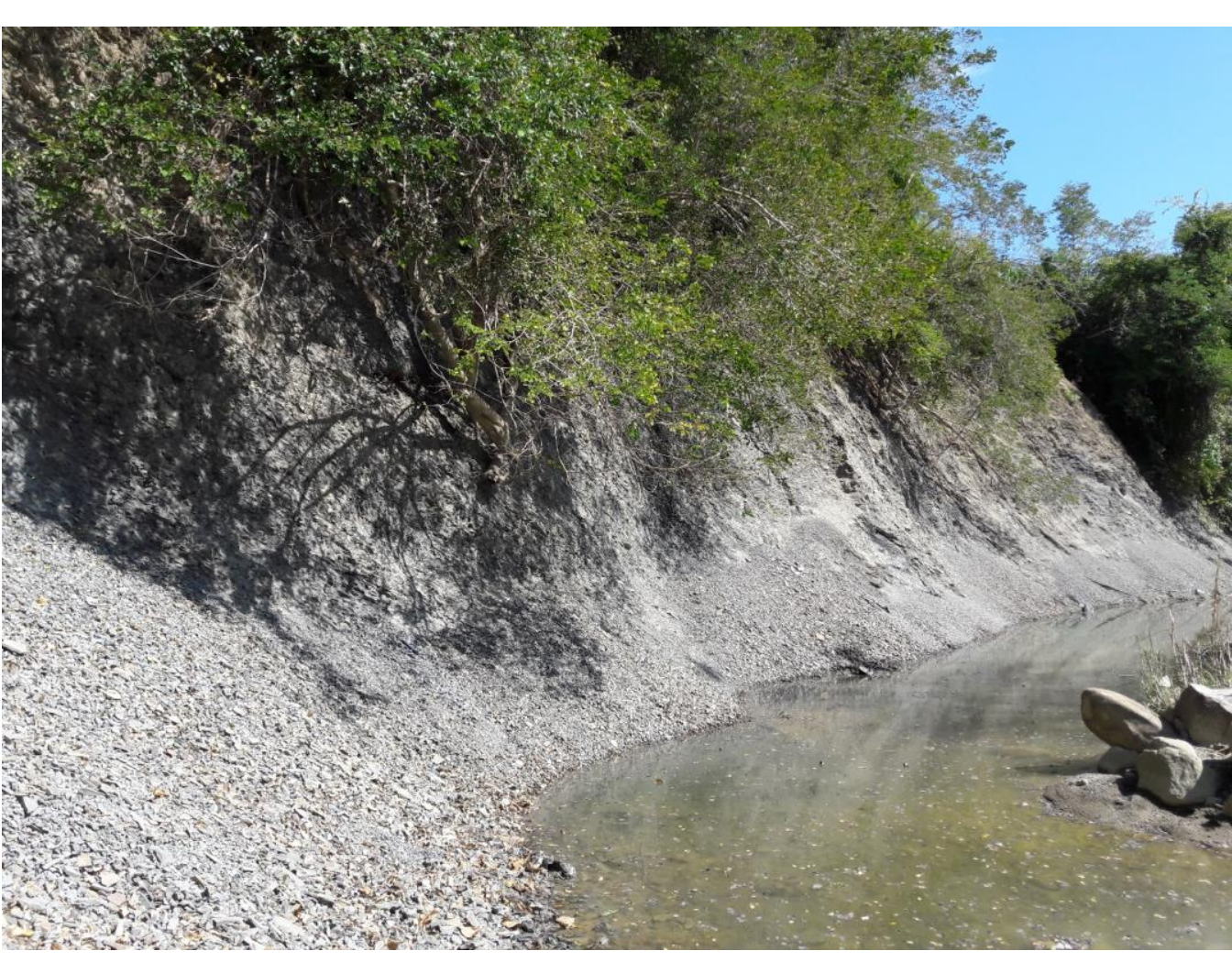

- Tabyin Formation

- Minbu Basin

- 16 samples in fresh blue-grey mudstones

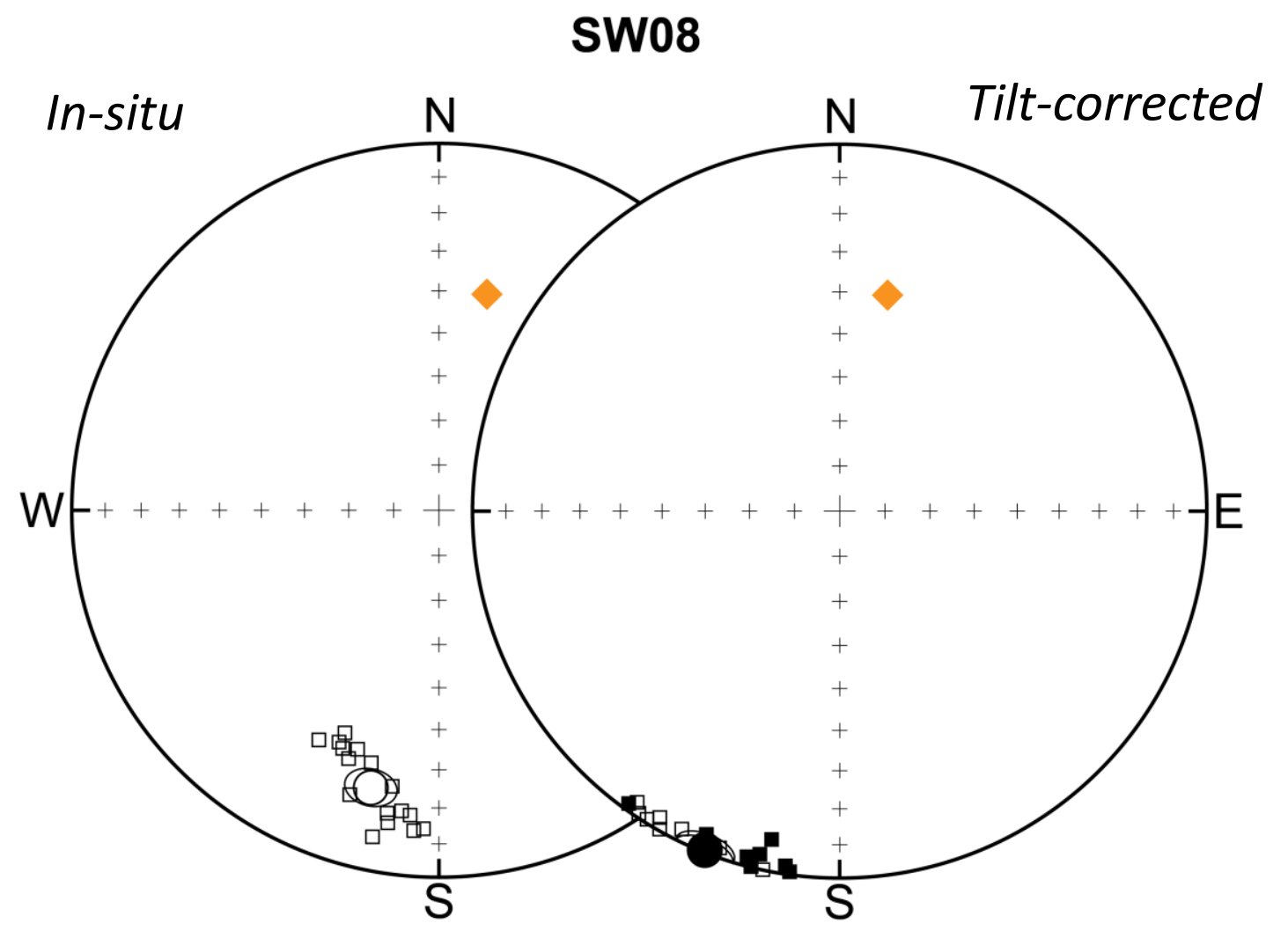

- Youngest site SW08

- Excellent grouping results, reverse polarity

- Both declination and inclination intermediate between older results and late Eocene results (see Slide 12) 


\section{Results: late Paleocene - middle Eocene}

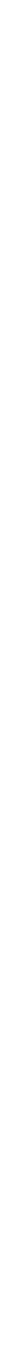




\title{
Results: late Paleocene - middle Eocene
}

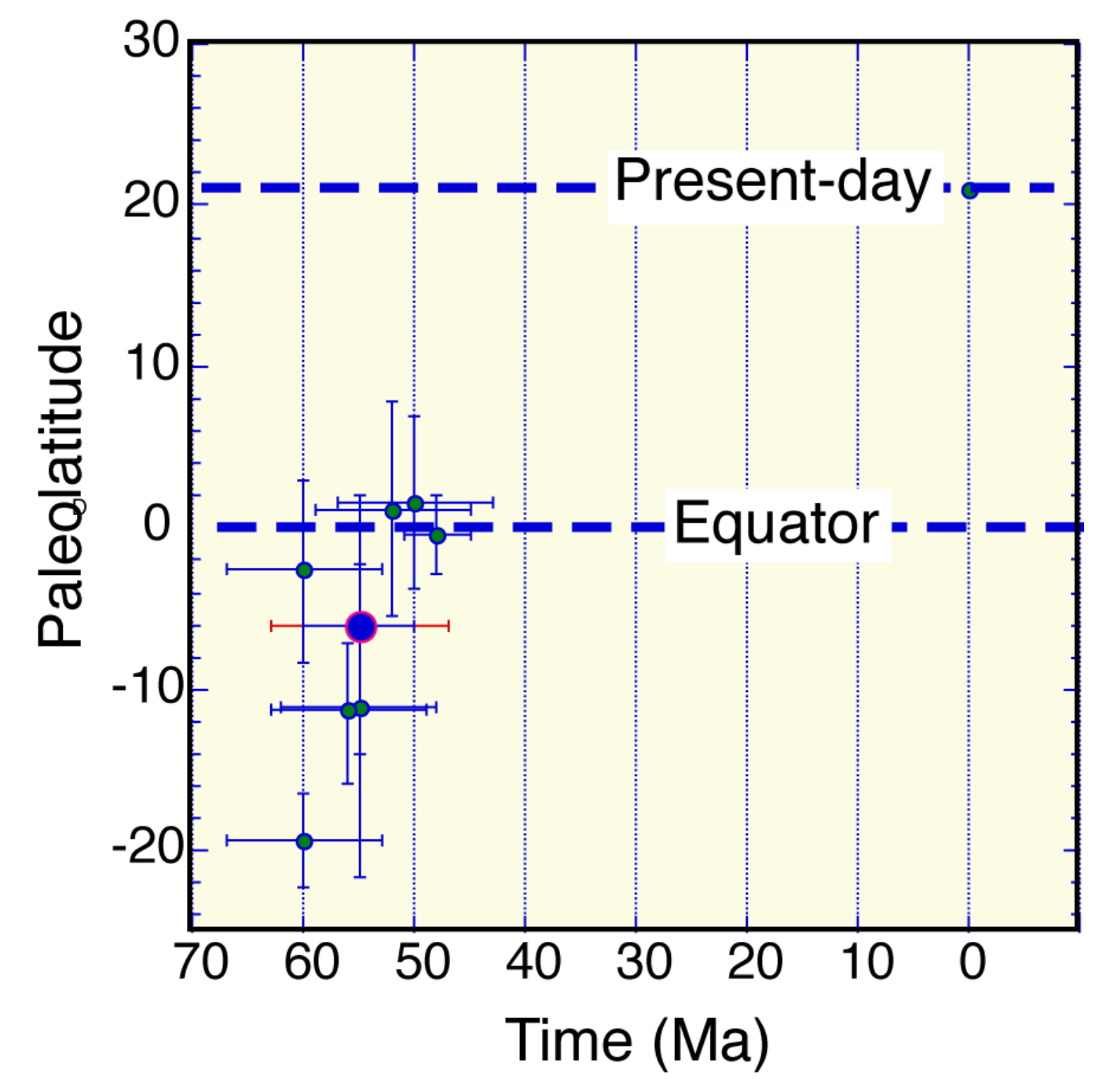

\author{
Inclinations:
}

- Less scatter in inclination, consistently negative to near-zero

$\rightarrow$ Southern hemisphere - near-equatorial latitudes Burma Terrane ( $\left.10^{\circ} \mathrm{S}\right)$

$\rightarrow$ Similar as position India at that time 


\section{Results: late Eocene}

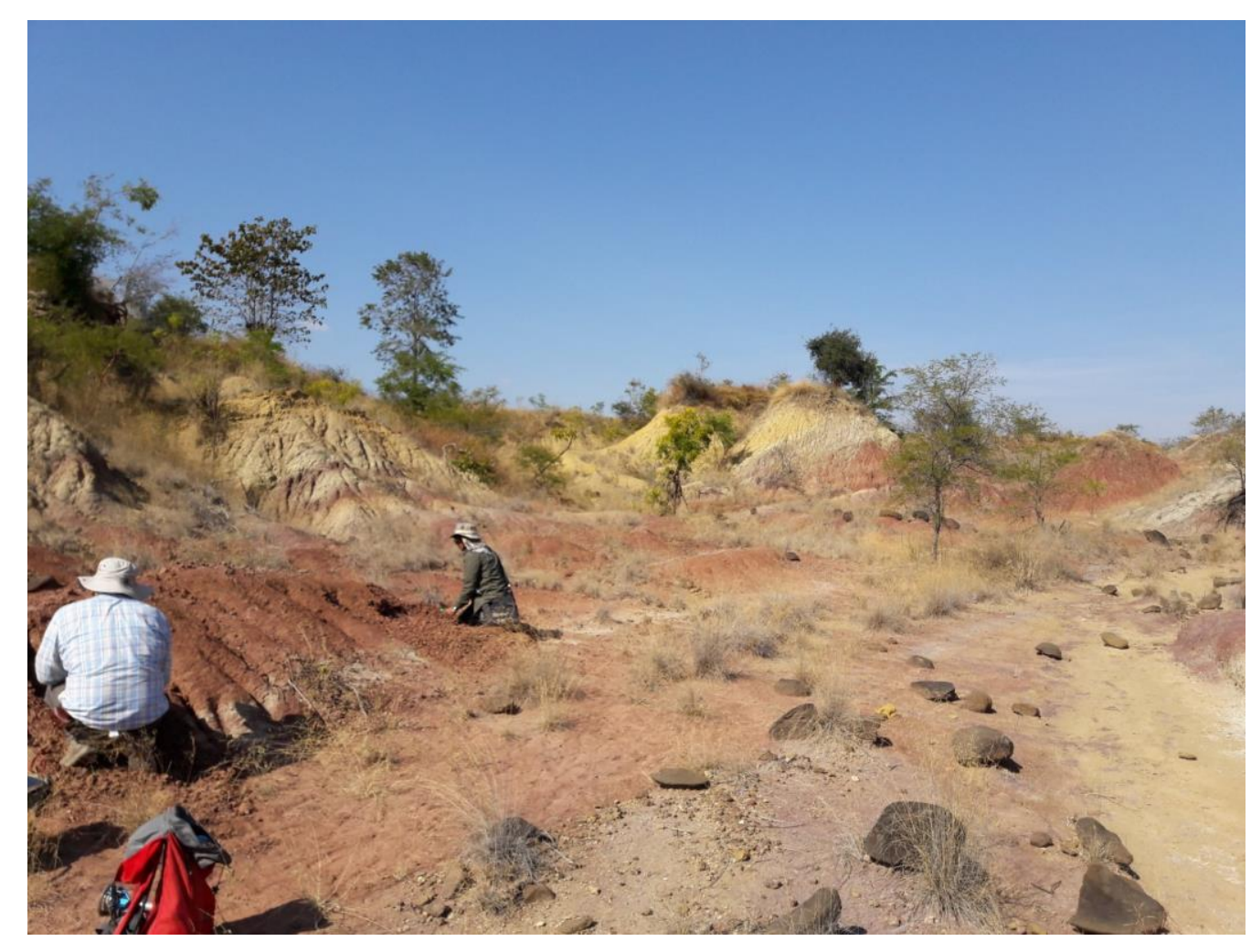

- Pondaung Formation

- Pondaung Ranges

- Strong overprint in present-day field, but 29 reliable samples from paleosols
Pondaung (PD) middle - late Eocene

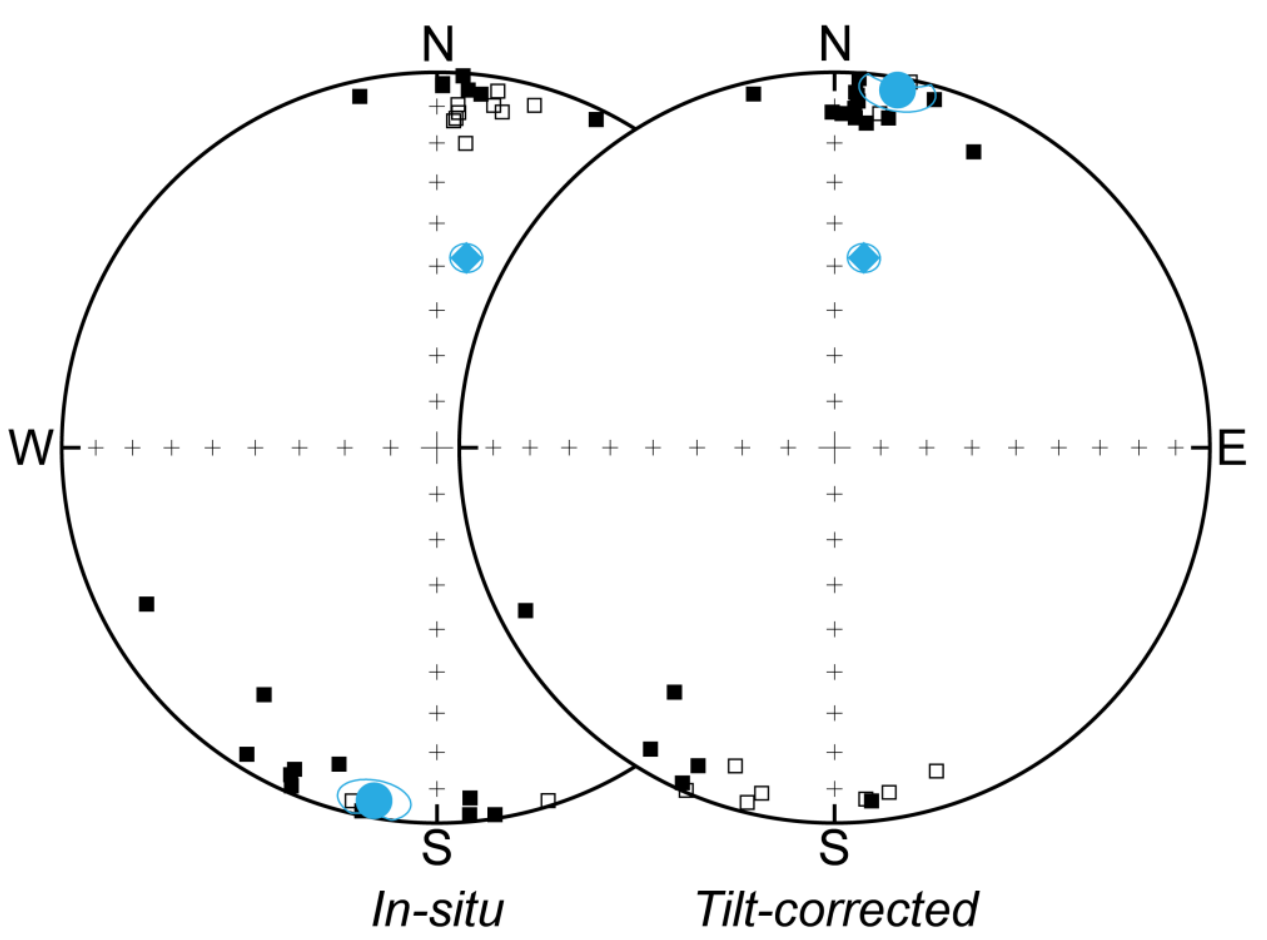

- Near-equatorial latitude $\left(2.5 \pm 1.3^{\circ} \mathrm{N}\right)$

- Negligible clockwise rotation $\left(3.0 \pm 4.4^{\circ}\right)$

- Effect inclination shallowing minimal: $2.5^{\circ} \mathrm{N} \rightarrow 4.2^{\circ} \mathrm{N}$

- Indistinguishable with published late Eocene result 


\section{Results: middle Oligocene}

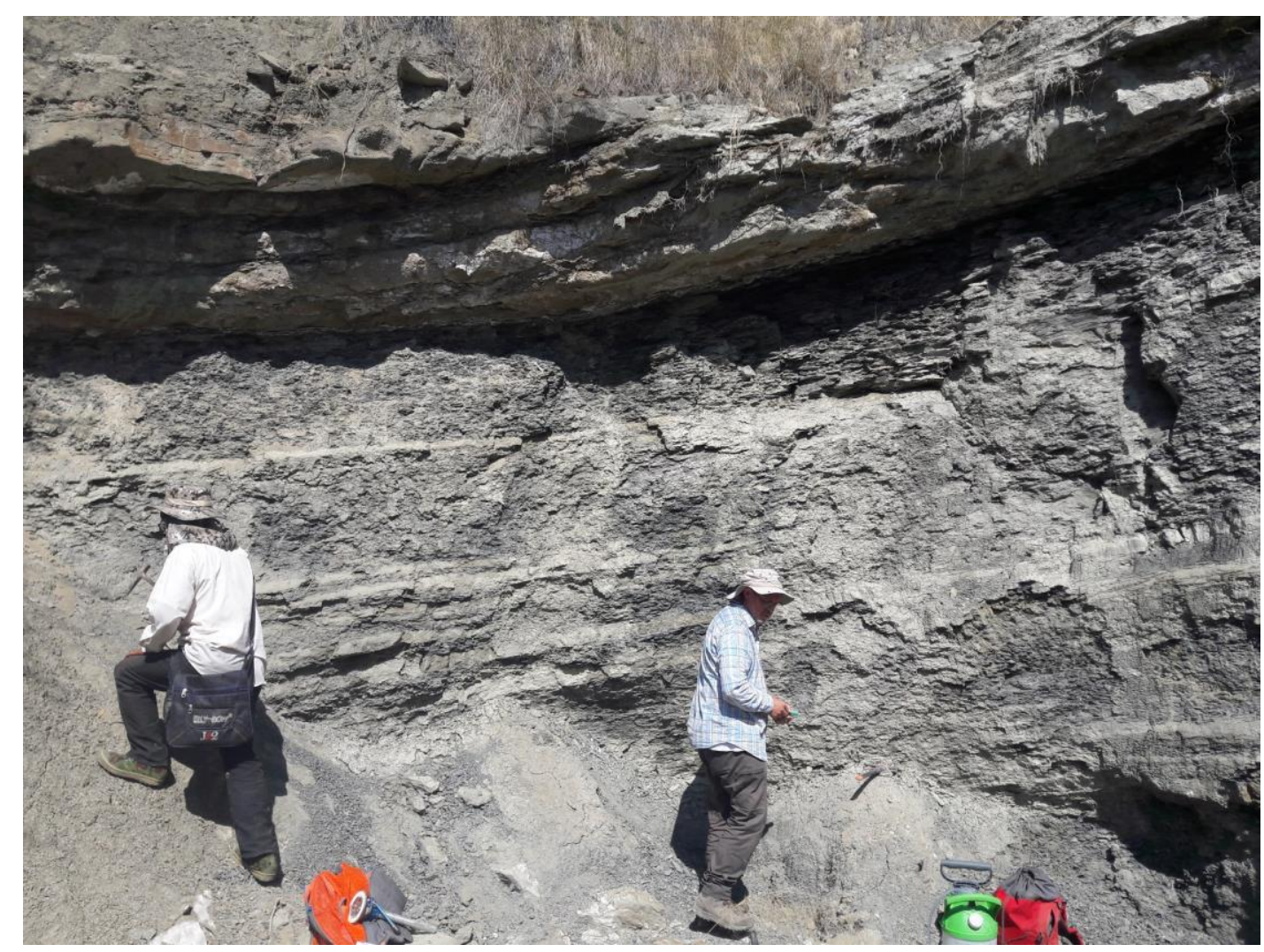

- Padaung Formation

- Minbu Basin

- 29 samples from fresh siltstones

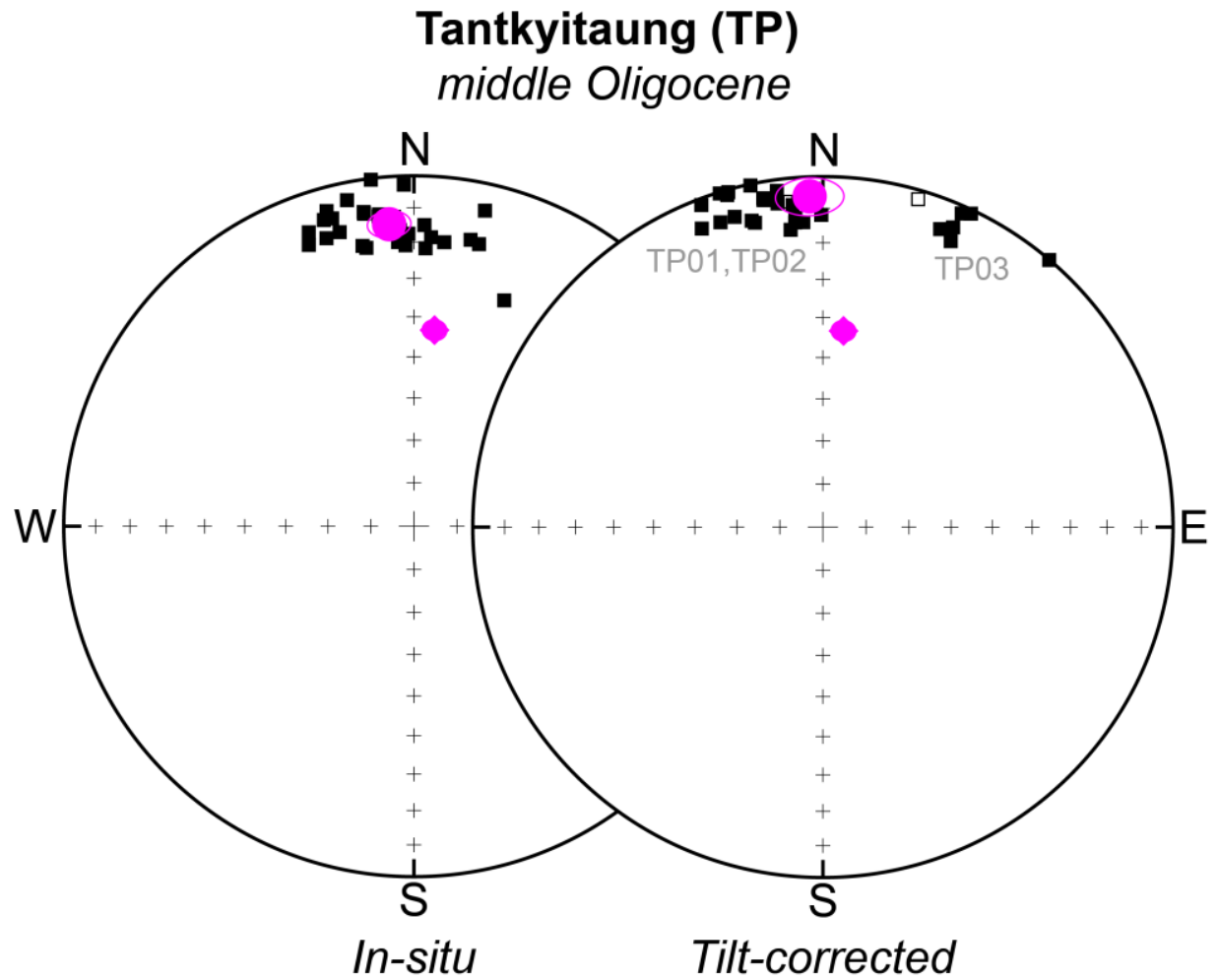

- Near-equatorial latitudes $\left(2.9 \pm 2.9^{\circ} \mathrm{N}\right)$

- Effect inclination shallowing minimal: $2.9^{\circ} \mathrm{N} \rightarrow 4.7^{\circ} \mathrm{N}$

- Minor rotations 


\section{Results: middle Miocene}

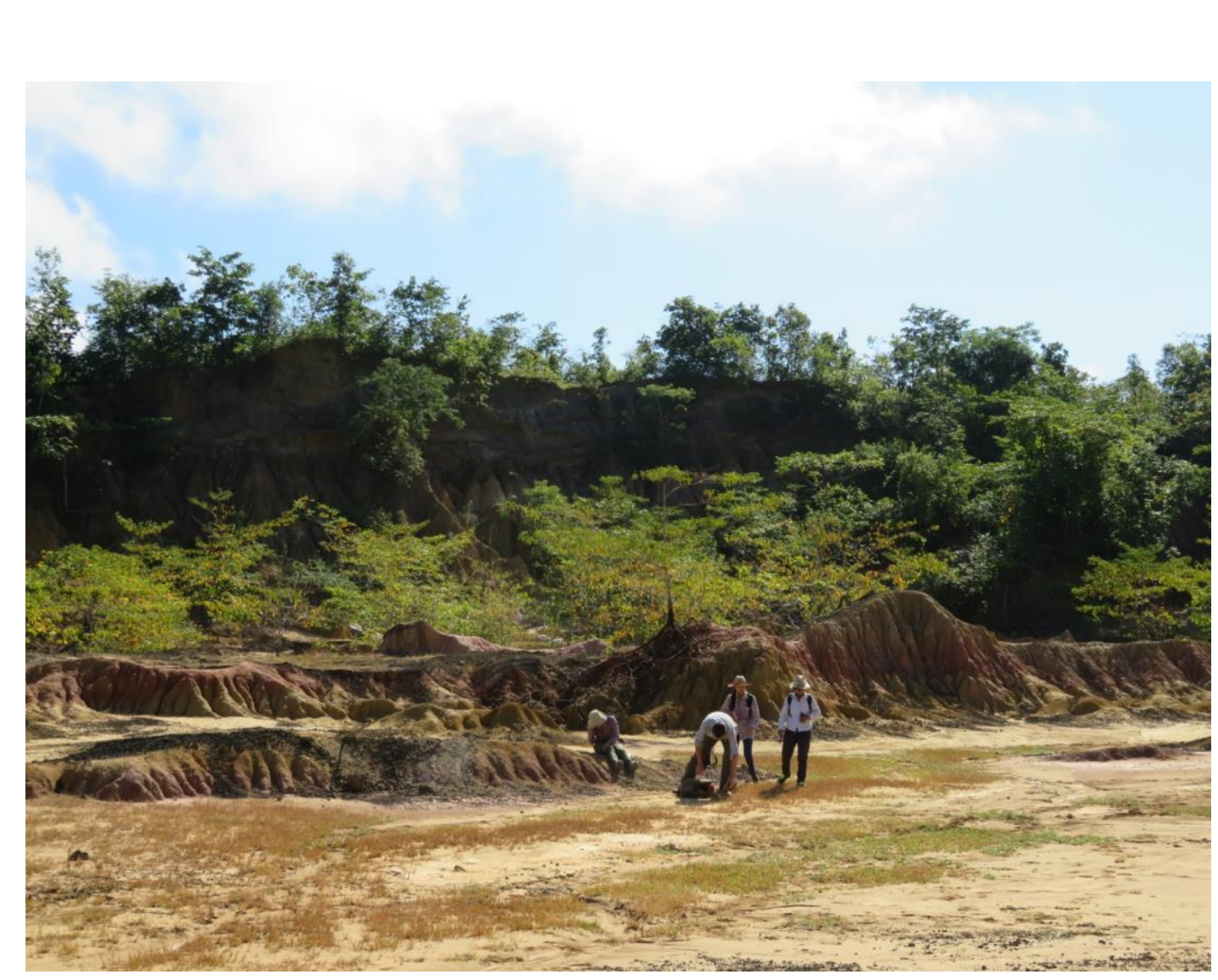

- Natma Formation

- 98 samples from paleosols

- Chindwin Basin

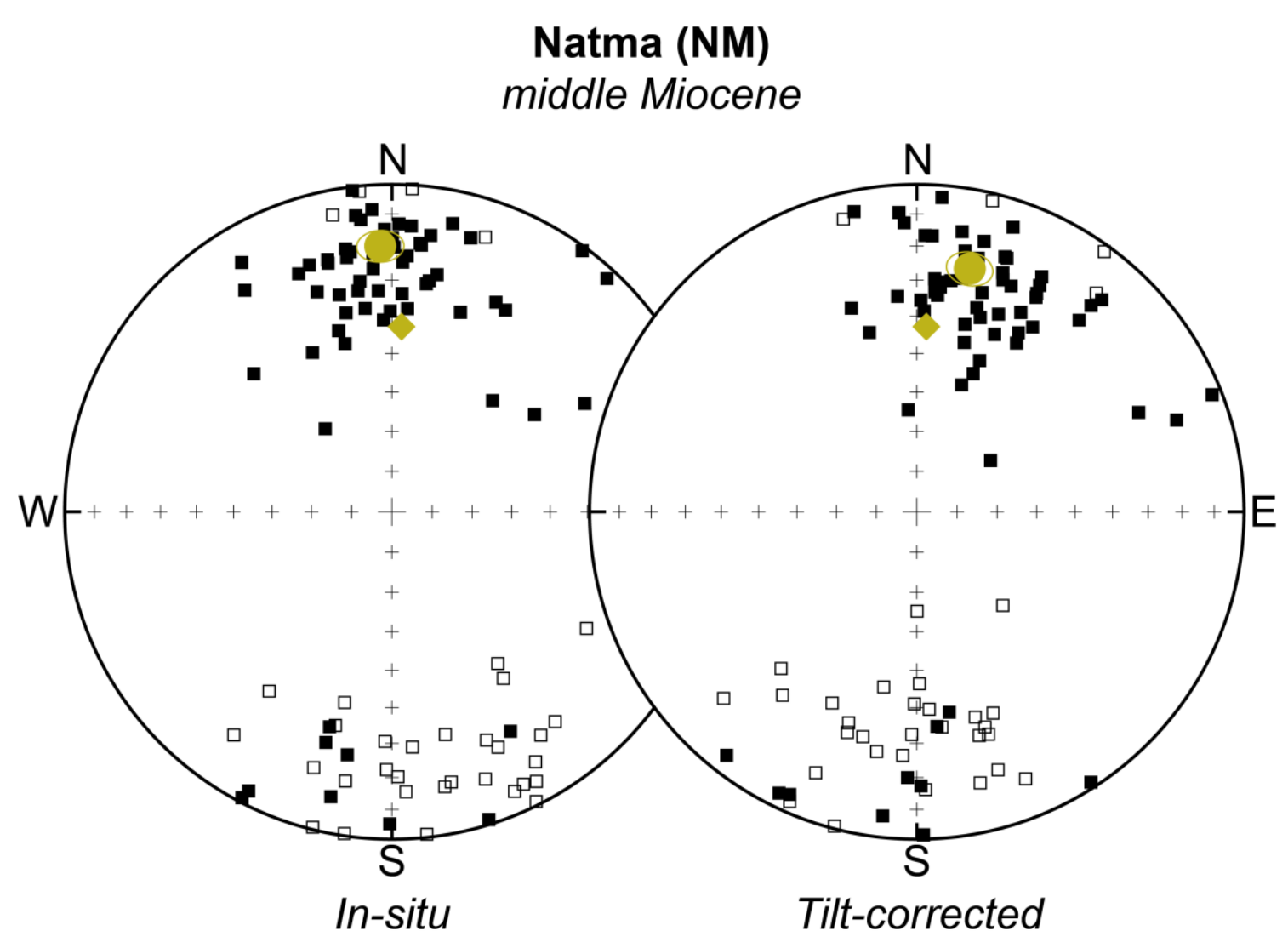

- Negligible clockwise rotation $\left(9.3 \pm 4.8^{\circ}\right)$

- Paleolatitude similar as offset estimates from dextral strikeslip Sagaing Fault $\left(13.1 \pm 2.9^{\circ} \mathrm{N}\right)$

$\rightarrow$ Therefore effect inclination shallowing minimal 


\section{Results: Latitudinal motion Burma Terrane}

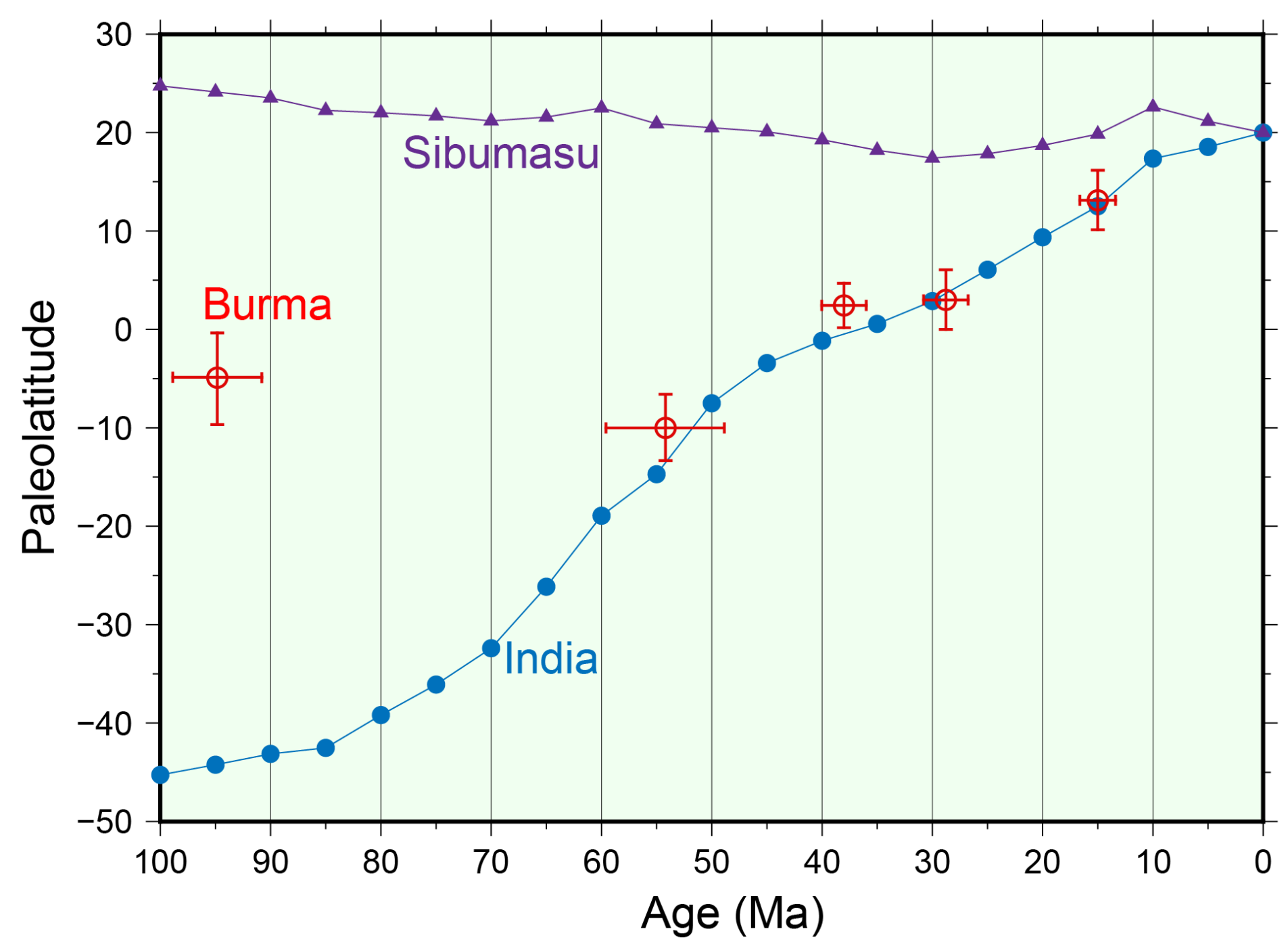

- Near-equatorial - southern latitudes for the Burma Terrane

- Coeval motion with India since late Paleocene - early Eocene

- Cenozoic collision with Asian margin (Sibumasu) 


\section{Work in progress: 58 Ma GPlates reconstruction}

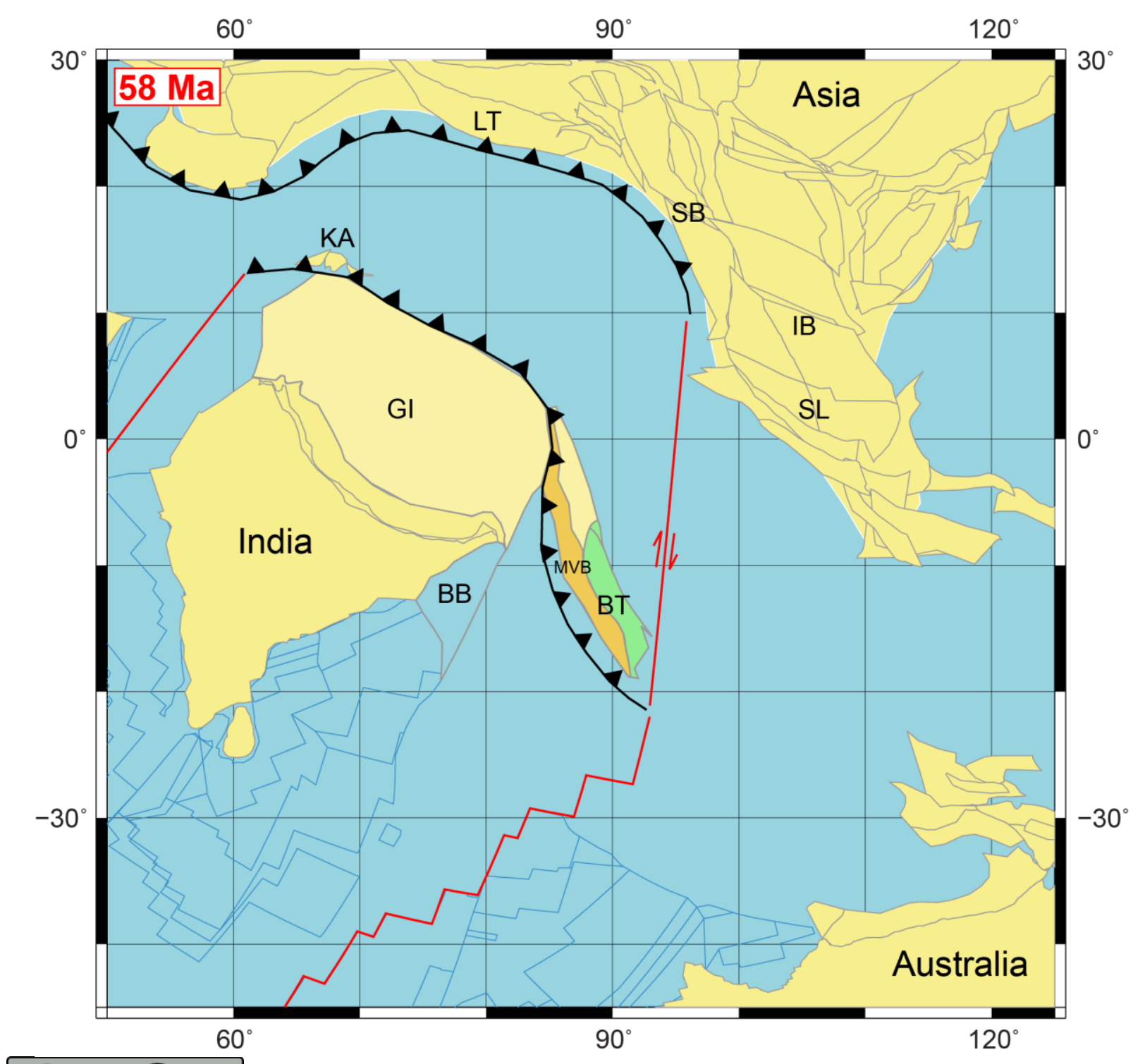

$\rightarrow$ Onset coeval motion Burma Terrane and India

\section{Questions:}

- Direct collision Burma Terrane and India? 


\section{Work in progress: $40 \mathrm{Ma}$ GPlates reconstruction}

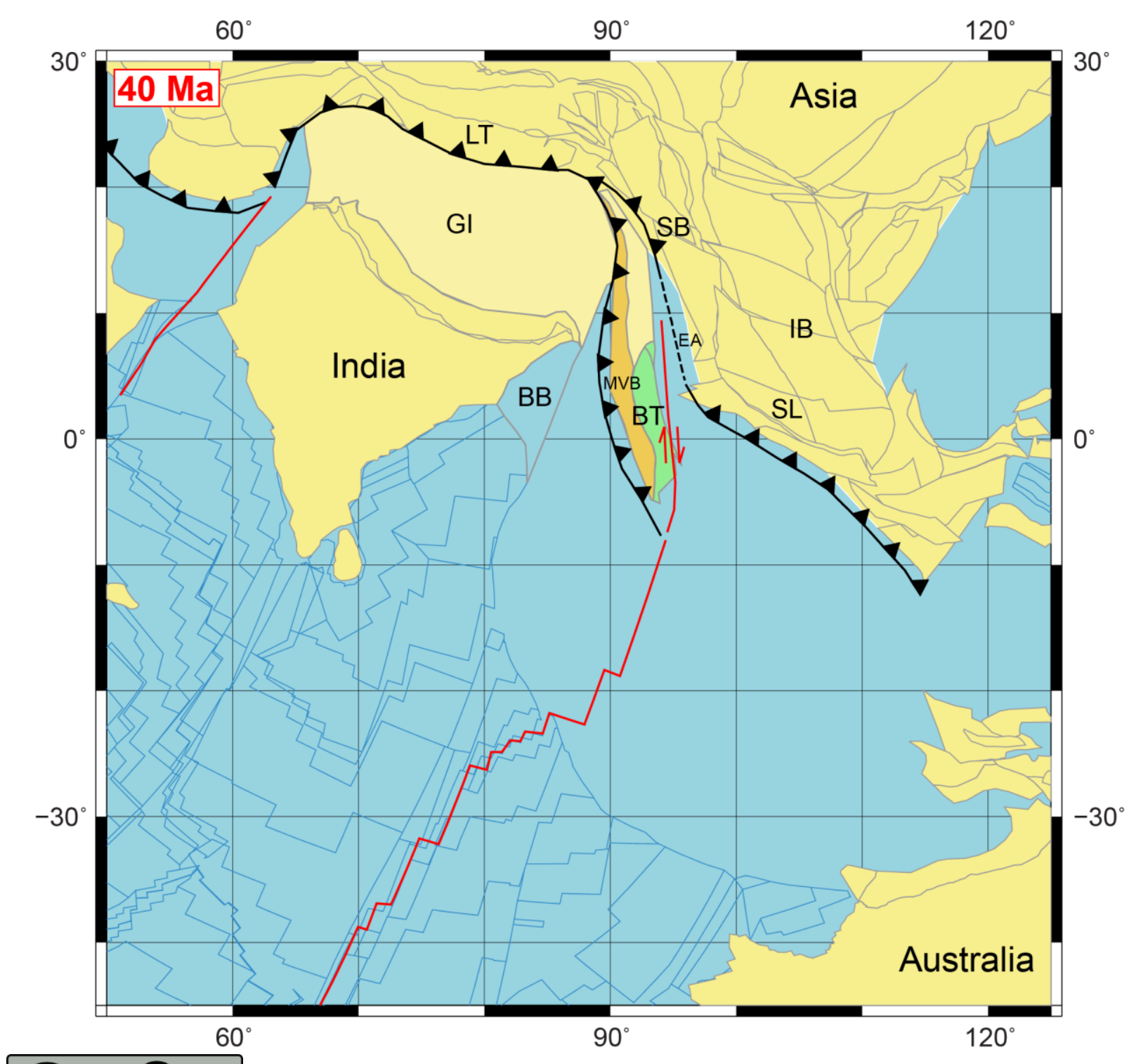

$\rightarrow$ Significant $\sim 2000 \mathrm{~km}$ northward motion with little rotation from late Eocene to present-day

$\rightarrow$ Little relative motion between India and the Burma Terrane

Questions:

- How long was the Burma Terrane isolated from Sibumasu?

$\rightarrow$ More western position would allow observed E-W extension in Eastern Andaman Sea (EA)

- India-Australia Transform? (Morley et al., 2020)

Next slide: Record of Burma Terrane - Sibumasu collision in sedimentary facies Burmese forearc? 


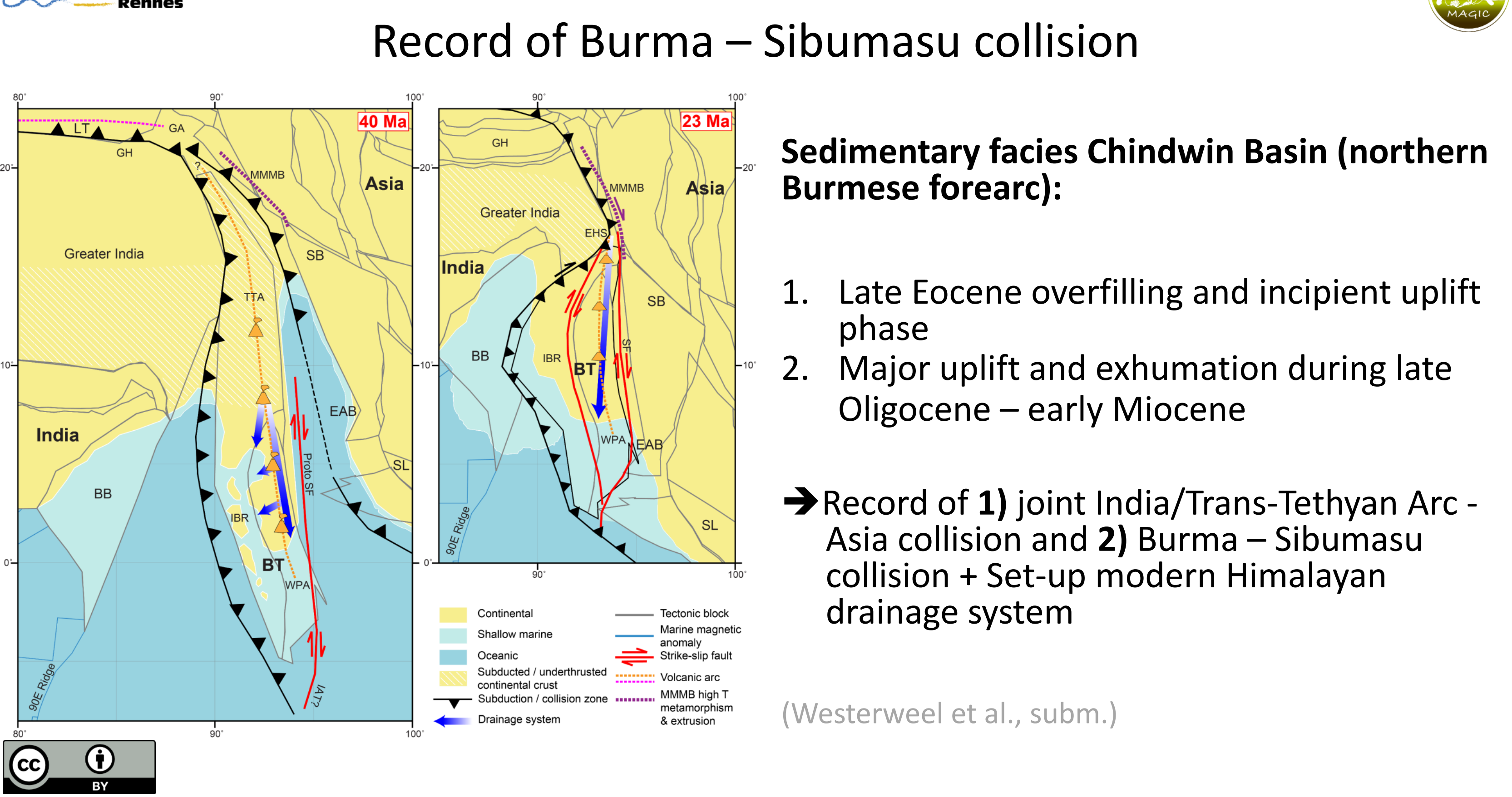




\section{Conclusions}

Key implications of our paleomagnetic results on the Burma Terrane:

- Late Cretaceous: southern hemisphere position distant from the Asian margin

- Late Paleocene - middle Eocene: incorporation onto Indian Plate and major clockwise rotation

- Middle Eocene - present: Northward motion coeval with India from near-equatorial position

- Late Oligocene - early Miocene: Collision with Sibumasu

$\rightarrow$ Fits best with Trans-Tethyan Arc setting

$\rightarrow$ Necessary to re-evaluate many aspects of the geology of Myanmar 


\section{References}

Cogne, J.-P., Besse, J., Chen, Y., \& Hankard, F. (2013). A new Late Cretaceous to Present APWP for Asia and its implications for paleomagnetic shallow inclinations in
Central Asia and Cenozoic Eurasian plate deformation. Geophysical Journal International, 192(3), 1000-1024. https://doi.org/10.1093/gji/ggs104

Hall, R. (2012). Late Jurassic-Cenozoic reconstructions of the Indonesian region and the Indian Ocean. Tectonophysics, 570, 1-41.

- Jagoutz, O., Royden, L., Holt, A. F., \& Becker, T. W. (2015). Anomalously fast convergence of India and Eurasia caused by double subduction. Nature Geoscience, 8(6), - Liu, C.-Z., Chung, S.-L., Wu, F.-Y., Zhang, C., Xu, Y., Wang, J.-G., ,.. Guo, S. (2016). Tethyan suturing in Southeast Asia: Zircon U-Pb and Hf-O isotopic constraints from
Myanmar ophiolites. Geology, 44(4), 311-314. https://doi.org/10.1130/G37342.1 - Metcalfe, I. (2013). Gondwana dispersion and Asian accretion: Tectonic and palaeogeographic evolution of eastern Tethys. Journal of Asian Earth Sciences, 66, 1-33.
https://doi.org/10.1016/j.jseaes.2012.12.020 - Mitchell, A., Chung, S.-L., Oo, T., Lin, T.-H. \& \& Hung, C.-H. (2012). Zircon U-Pb ages in Myanmar: Magmatic-metamorphic events and the closure of a neo-Tethys ocean?
Journal of Asian Earth Sciences, 56, 1-23. https://doi.org/10.1016/i.jseaes.2012.04.019 - Morley, C. K., Tin Tin Naing, Searle, M., \& Robinson, S. A. (2020). Structural and tectonic development of the Indo-Burma ranges. Earth-Science Reviews, $200,102992$.
https://doi.org/10.1016/j.earscirev.2019.102992

- Najman, Y., Sobel, E. R., Millar, I., Stockli, D. F.. Govin, G., Lisker, F., ... Kahn, A. (2020). The exhumation of the Indo-Burman Ranges, Myanmar. Earth and Planetary

- Petterson, M. G. (2019). The plutonic crust of Kohistan and volcanic crust of Kohistan-Ladakh, north Pakistan/India: lessons learned for deep and shallow arc processes.
Geological Society, London, Special Publications, 483(1), 123-164. https://doi.org/10.1144/SP483.4 Pubellier, M. (2008). Structural map of eastern Eurasia. CCGM.

- Pubellier, M. (2008). Structural map of eastern Eurasia. CCGM

- Rangin, C. (2018). The western Sunda basins and the India/Asia collision: an atlas. Geotecto, Paris, France.

Replumaz, A., Negredo, A. M., Guillot, S., \& Villaseñor, A. (2010). Multiple episodes of continental subduction during India/Asia convergence: Insight from seismic

- Replumaz, A., Guillot, S., Villaseñor, A., \& Negredo, A. M. (2013). Amount of Asian lithospheric mantle subducted during the India/Asia collision. Gondwana Research,

Richter, B. \& Fuller, M. (1996). Palaeomagnetism of the Sibumasu and Indochina blocks: Implications for the extrusion tectonic model. Geological Society, London,
Special'Publications, 106(1), 203-224.

- Royden, L. H., Burchfiel, B. C., \& van der Hilst, R. D. (2008). The geological evolution of the Tibetan Plateau. science, 321(5892), 1054-1058.

Van Hinsbergen, D. J., Kapp, P., Dupont-Nivet, G., Lippert, P. C., DeCelles, P. G., \& Torsvik, T. H. (2011a). Restoration of Cenozoic deformation in Asia and the size of

- Sevastjanova, I., Hall, R., Rittner, M., Paw, S. M. T. L., Naing, T. T., Alderton, D. H., \& Comfort, G. (2016). Myanmar and Asia united, Australia left behind long ago.

15.02.001

Van Hinsbergen, D. J., Lippert, P. C., Dupont-Nivet, G., McQuarrie, N., Doubrovine, P. V., Spakman, W., \& Torsvik, T. H. (2012). Greater India Basin hypothesis and a two-

- van Hinsbergen, D. J. J., Lippert, P. C., Li, S., Huang, W., Advokaat, E. L., \& Spakman, W. (2018). Reconstructing Greater India: Paleogeographic, kinematic, and

Westerweel, according to palaeomagnetic data. Nature Geoscience. https://doi.org/10.1038/s41561-019-0443-2 Yao, W., Ding, L., Cai, F., Wang, H., Xu, Q., \& Zaw, T. (2017). Origin and tectonic evolution of upper Triassic Turbidites in the Indo-Burman ranges, West Myanmar.
Tectonophysics, 721, 90-105. https://doi.org/10.1016/j.tecto.2017.09.016 - Zahirovic, S., Matthews, K. J., Flament, N., Müller, R. D., Hill, K. C., Seton, M., \& Gurnis, M. (2016). Tectonic evolution and deep mantle structure of the eastern Tethys
since the latest Jurassic. Earth-Science Reviews, 162, 293-337. https://doi.org/10.1016/i.earscirev.2016.09.005 - Zhang, P., Mei, L., Hu, X., Li, R., Wu, L., Zhou, Z., \& Qu, H. (2017). Structures, uplift, and magmatism of the Western Myanmar Arc: Constraints to mid-Cretaceous-
Paleogene tectonic evolution of the western Myanmar continental margin. Gondwana Research, 52, 18-38. https://doi.org/10.1016/j.gr.2017.09.002 